\title{
Social housing residents' community participation under the impact of lease period restrictions
}

\author{
Hui-Chun Tsuang $^{1 *}$, Ko-Chiu Wu ${ }^{1}$, Kuang-Hui Peng ${ }^{1}$ \\ 1 College of Design, National Taipei University of Technology \\ * Corresponding Author, Email: chris.ts@ mail2000.com.tw
}

Received: Jan 09, 2020 Accepted: Oct 18, 2020

Keywords: Residents' participation, Social housing, Reduce social vulnerability, Resilient communities, Lease term restrictions, Egoism

\begin{abstract}
Community participation is the foundation of a community's healthy environment and sustainable development. Social housing can provide people without their own homes and underprivileged groups with more secure conditions to live and work and thereby realize housing justice and reduce social vulnerability. In terms of community management, residents' engagement in community affairs can dramatically reduce the subsequent burden of environmental maintenance and community management, which encourage residents in the community to actively pass on the habit of maintenance and to collectively create resilient and sustainable communities. However, lease term restrictions in Taiwan's social housing policy stipulates that ordinary tenants can only rent the house for 6 years at a maximum and tenants with special conditions for 12 . This study attempts to understand whether lease term restrictions affect residents' willingness to participate in community affairs. In addition, we also try to find out how to motivate residents to participate in community construction under the existence of lease term restrictions. The scope of this study focuses on citizens who qualified to rent social housing in the Greater Taipei area (including Taipei City and New Taipei). We designed a questionnaire for our target audience, tested its reliability and validity and picked random-selected samples to finish the questionnaire. Analyzing from the perspective of Egoism, we find out that the result of this research shows that residents do not commonly avoid participation in community affairs. Although lease term restrictions do have some effects on residents' willingness to participate, they are still willing to participate since issues of safety and environmental quality have a direct impact on their lives. However, the residents' chief consideration is how time spent in participation affects one's time. Also, though substantial returning benefit is not the main consideration when deciding whether to participate, it does effectively boost residents' willingness. Furthermore, community member relations is found to have a positive correlation with their willingness to participate.
\end{abstract}

\section{INTRODUCTION}

Economic and political conditions of a country inevitably affect its development of social housing. In order to prevent social exclusion, the quality of social housing must be at least equivalent to the nation's average housing quality (Petković-Grozdanović et al., 2017). Taiwan's current social housing is given the responsibility to adjust the housing market, provide social care and maintain a 
better dwelling environment. Externally it must be at least equivalent to the nation's average housing quality willingness toward maintenance, and sustainable development is under the pressure of limited resources and funding. After the land privatization and under the influence of the traditional Chinese concept "owning land equals owning wealth", the free housing market has long dominated Taiwan's housing system. According to the 2015 Report on the Survey of Family Income and Expenditure conducted by the Directorate General of Budget, Accounting and Statistics (DGBAS) of Executive Yuan, Taiwan's homeownership rate has reached $84.23 \%$. Due to the high homeownership rate, social housing which is only for rent but not for sale challenges the traditional concept of owning real estate. However, it is also the excessive development of the free housing market that causes today's high housing prices, which can only be adjusted by the public housing policy. So far, since the supply and demand of social housing have not reached a balance during the early period, lease term restrictions remain an expedient policy that can take care of more residents with house requirements, but may also affect residents' willingness and motivation to jointly participate in community affairs and maintain the living environment.

For house management units, residents' engagement in community affairs can remarkably reduce the subsequent burden of environmental maintenance and community management, which encourages residents in the communities to actively pass on the habit of maintenance and to collectively create resilient and sustainable communities. However, lease term restrictions in Taiwan's social housing policy stipulate that ordinary tenants can only rent social housing for 6 years at a maximum and tenants with special conditions for 12 . Does the restriction affect the willingness of residents to participate in community affairs? In addition, how does the community create residents' motivation to participate while the lease term restrictions exist? The above questions are issues we would like to clarify.

Based on the research motivation mentioned above, this study will target those who are eligible to rent social housing in the Greater Taipei area (including Taipei City and New Taipei City) to explore their willingness and considerations for community participation under the lease term restrictions. After research and inductive analysis, the suggestion concluded in this study will be provided for social housing management units as a reference to carry out the community construction. The purpose is as follows:

(1) To investigate and understand the extent to which social housing lease term restrictions affect residents.

(2) To investigate and understand residents' motivation to participate in community affairs under the influence of lease term restrictions.

The result of this study shows that the current leasing term restrictions of social housing may affect the residents' willingness of community participation to some extent, but residents still have a rational attitude toward community participation. Responses to negative questions, such as not participating or depending on the mood of the day, are more towards disagreement. As for easier leisure activities, festival activities, activities which give substantial benefits in return and activities maintaining environmental hygiene and safety, their impacts on participant willingness are greater than the impact of the lease term restrictions. Personal time allowance and direct impacts on the individual or their family members are an individual's focal point of consideration. The chance to make effective changes causes a greater impact on peoples' willingness and consideration than lease term 
restrictions, and the correlation between good community relations and participation willingness and consideration is positive.

\section{LITERATURE REVIEW}

\subsection{Taiwan social housing}

The current social housing mainly tries to solve citizens' housing problems. Built and subsidized by the government, these houses are restricted to socially and economically underprivileged citizens or citizens who do not have an appropriate place to live in so that these people can also have suitable accommodation. The early social housing in Taiwan was called public housing. Unlike the current social housing which is only for rent but not for sale, the public housing is mostly sold to people with a government subsidy, but is less commonly handled in the rental form. In order to reduce the price for citizens, public housing was thereby built at a low cost. Though it has met the basic requirement for qualified residents to live in, problems of the poor quality of the social community and the maintenance and management of buildings have emerged, causing the public to form a stereotype of "Slums" and "Not-In-My-Back-Yard Buildings" for Public housing (Liao, 2012). To date, in response to Taiwan's economic and social changes, a "Housing Act" ("the Act") has been enacted to replace the "Public housing Regulations" in order to cope with the housing development in the future. The act was promulgated and implemented in 2017 and its formulation principle is clarified in Article 1: “...to protect citizens' right to housing, establish a robust housing market, improve the quality of housing, and thus allow all citizens to enjoy suitable housing and a dignified living environment." Apart from formulating a special regulation for public housing, the government considers the quality of all dwellings, including public housing, in this act. In Chapter 3 of the Act, public housing is renamed social housing, which shows that this is one of the important aspects of the Housing Act. The differences between the current social housing and the original public housing are demonstrated in Table 1.

Table 1. Comparison table between current and original public housing

\begin{tabular}{|c|c|c|}
\hline $\begin{array}{l}\text { Public } \\
\text { housing }\end{array}$ & Current social housing & Original Public housing \\
\hline $\begin{array}{l}\text { Leading } \\
\text { operator }\end{array}$ & Public sector, civil society & Public sector \\
\hline $\begin{array}{l}\text { Mode of } \\
\text { operation }\end{array}$ & $\begin{array}{l}\text { Only for rent: } \\
\text { "related rental regulations of Taipei City and New } \\
\text { Taipei City are restricted for lease term; i.e. for } \\
\text { those who are eligible tenants, a maximum of } 6 \\
\text { years in the case of ordinary tenants and a } \\
\text { maximum of } 12 \text { years in the case of tenants with } \\
\text { special status" }\end{array}$ & $\begin{array}{l}\text { For sale or for rent } \\
\text { (The original public housing } \\
\text { is mostly for sale) }\end{array}$ \\
\hline $\begin{array}{l}\text { Eligible } \\
\text { object }\end{array}$ & $\begin{array}{l}\text { Families or individuals that do not own a house or } \\
\text { whose income and assets are below the standard. } \\
\text { At least } 30 \% \text { of the social housing shall be } \\
\text { provided for people with special conditions such } \\
\text { as low-income households, people raising three or }\end{array}$ & Family with lower income \\
\hline
\end{tabular}




\begin{tabular}{lll}
\hline & $\begin{array}{l}\text { more minor children, senior citizens aged } 65 \text { and } \\
\text { above, victims of disaster and homeless people. }\end{array}$ \\
\hline Purpose & $\begin{array}{l}\text { Allow all citizens to enjoy suitable housing and a } \\
\text { dignified living environment. }\end{array}$ & $\begin{array}{l}\text { Provide housing for families } \\
\text { with lower incomes }\end{array}$ \\
\hline Value & $\begin{array}{l}\text { Social housing is designed to satisfy the housing } \\
\text { requirement in a rental way; under this goal, the }\end{array}$ & $\begin{array}{l}\text { The government sells or rents } \\
\text { non-profit housing so that the }\end{array}$ \\
& $\begin{array}{l}\text { behavior of residents will be managed. } \\
\text { Furthermore, the government aims to reduce the }\end{array}$ & underprivileged groups can \\
& use of housing as a profit-making commodity so & also live in their own homes. \\
that a healthy housing market can be built and the & \\
quality of dwellings can be improved. & \\
\hline
\end{tabular}

(Sources: Past and abolished Public Housing Act, Housing Act, Renting Regulations by Taipei City of Social Housing, The New Taipei City Government handles the stipulations for the qualification review of the rental of social housing).

The above comparison shows that acts, regulations and policies related to public housing have moved from public housing which solves economically disadvantaged groups' housing problem to social housing which attempts to raise the overall dwelling quality. Furthermore, the scope of eligible citizens has extended from socially and economically disadvantaged groups to people who do not have their own house. The non-profit-oriented public housing aims to cater to the needs of all citizens including the socially disadvantaged and vulnerable groups, and to ensure the environmental quality of their communities. Regarding the quality of a residential dwelling environment (Flint, 2004), article 41 of the Housing Act states that local bureaus shall actively hold educational training about community construction, housing and community organizations to improve the overall housing quality. Many social housing managers hope to adjust tenant behavior, have tenants participate in the construction of the residential environment and increase their responsibility and autonomy. However, will the lease term restrictions affect the willingness of residents to participate in community affairs? This study is conducted with citizens in the Greater Taipei area (including Taipei City and New Taipei City) who are eligible and have a willingness to rent.

\subsection{Community consciousness}

Social sustainability at the community level includes social relations within the community and covers the involvement of the public or at least the stakeholders in the community activities, and their formulation (Wei et al., 2016). Community governance must organize and implement public participation, fully cultivate, and give play to the positive role of community organization (Huang et al., 2018). In the environment of the metropolitan area, the community consciousness to a certain degree is relevant to residents' willingness to participate in community affairs. Community consciousness differs between urban and rural areas. As the economy, career, life paces and diversity has changed, a profound contrast has formed between urban and rural life. In a rapidly changing, complex and stimulating environment, urban residents often develop an indifferent attitude towards their environment (Simmel, 2012). Urban life has changed peoples' relationships. In the early 20th century, research from the Chicago School showed that urbanization, compared to traditional societies, has brought loneliness, 
isolation, abnormality or stress (Maya-Jariego \& Holgado, 2015). It is considered that the social connection of Taiwanese society - the relative network and neighborhood interactions - has a direct influence on one's community consciousness, but rather, the length of time that one stays in the community has no decisive influence ( $\underline{\mathrm{Li}, 2010})$. Chang and Sung (2010) point out that community consciousness has a positive correlation with people's participation; only a good partnership can cluster people's awareness and promote participation. A good inhabitant relationship and network make the community stronger (Wang, 2014). Given the environment in the metropolitan area, the community consciousness has a certain degree of relevance to residents' participation in community affairs. This study refers to their survey and other questionnaires that were used in related research of community consciousness and popular participation to design our questionnaire surveying people's willingness and considerations to participate. We hope that by the result of this questionnaire, we can understand problems which residents are facing when they participate in community affairs under social housing's lease term restrictions.

\section{RESEARCH METHOD}

The questionnaire was designed to investigate the residents' willingness and consideration to participate in social housing community affairs. Since the Greater Taipei area is the administrative and economic center of Taiwan, its social welfare, public transport system, and job opportunities are all better than other areas. On the other hand, its living price level is higher and its housing price has remained consistently high (Tsuang \& Peng, 2018). Therefore, there is also a high demand for social housing so that residents' expenses can be reduced. The questionnaire targets people who are eligible and willing to rent in the Greater Taipei area (including Taipei City and New Taipei City) as the research objects, and the survey was conducted through random sampling. 31 distributed reliability questionnaires were collected for its reliability test and then formal questionnaires were randomly distributed to eligible objects. 121 questionnaires were collected, three of which were invalid and 118 of which were valid questionnaires. The availability rate of collected questionnaires was $97.52 \%$. After the relevant questionnaires were collected, they were encoded into a computer. SPSS19 and Excel2013 were applied for the statistical calculation. The statistical values were reviewed by adopting mean value and standard deviation. Also, since our targets, people who are eligible and willing to rent social housing, whether in ordinary or special conditions, can only be counted as a single sample, we do not have the actual number of the population to infer a reasonable number of samples. Therefore, we apply the Kolmogorov-Smimor one-sample test of nonparametric statistics to test the significance level. Finally, after coding the statistical results mentioned above and accomplishing the research analysis, we probe into people's motivation for community participation under the lease term restrictions and give suggestions.

\subsection{Research object}

This study targeted the citizens who are eligible to rent social housing in the Greater Taipei area (Taipei City, New Taipei City) and the questionnaire was 
distributed to random targets. In order to produce deliverable research of social housing, we picked 72 copies out from the 118 available ones to analyze. These 72 copies consist of answers from people who were already accommodated in social housing as well as people who are eligible and willing to rent social housing. (1)16 copies are from people who are already accommodated in social housing, accounting for $14 \%$. (2) 52 copies are from people with an ordinary condition who are eligible and willing to rent, accounting for $44 \%$. (3) 4 copies are from people with a special condition who are eligible and willing to rent, accounting for 3\%; (4) 11 copies are from people who are eligible to rent but not interested in renting, accounting for 9\%; (5) 35 copies are from people who are not eligible to rent, accounting for 30\%; (1)-(3) are qualified copies, the total number of which is 72 . The proportions and people's identity are shown in Figure 1 .

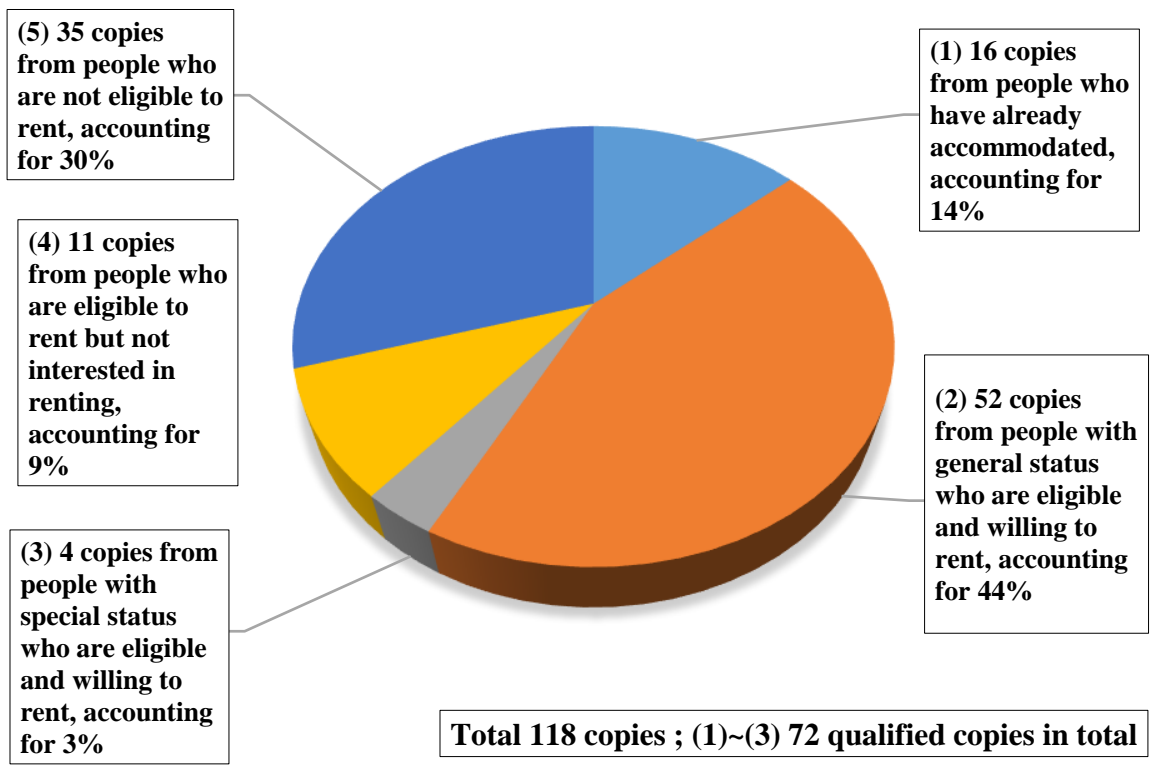

Figure 1. The proportion and status of people who answer the questionnaire

\subsection{Research tools}

This study adopts a "Questionnaire that investigates Social Housing Residents' Willingness of Community Participation" as the research tool. The questionnaire contains two parts:

\subsubsection{Introduction and basic information of this questionnaire}

In order to let the questionnaire be done smoothly, a preface is written on the first page of the questionnaire to explain the source and the purpose of the research. The basic information section asks questions regarding gender, age, current location, category of occupation, education level, marital condition, whether there is a child under the age of 18 at home, whether they serve a position in a community self-governing body, and one's identity. 


\subsubsection{Willingness and consideration of residents' community participation}

We designed the questionnaire to investigate social housing residents' community participation by using a Likert Scale. Choices: 1) Strongly disagree, 2) Disagree, 3) Sometimes agree, 4) Agree and 5) Strongly agree, are taken as the evaluation model. The designed items are shown in Table 2:

Table 2. Community participation questionnaire

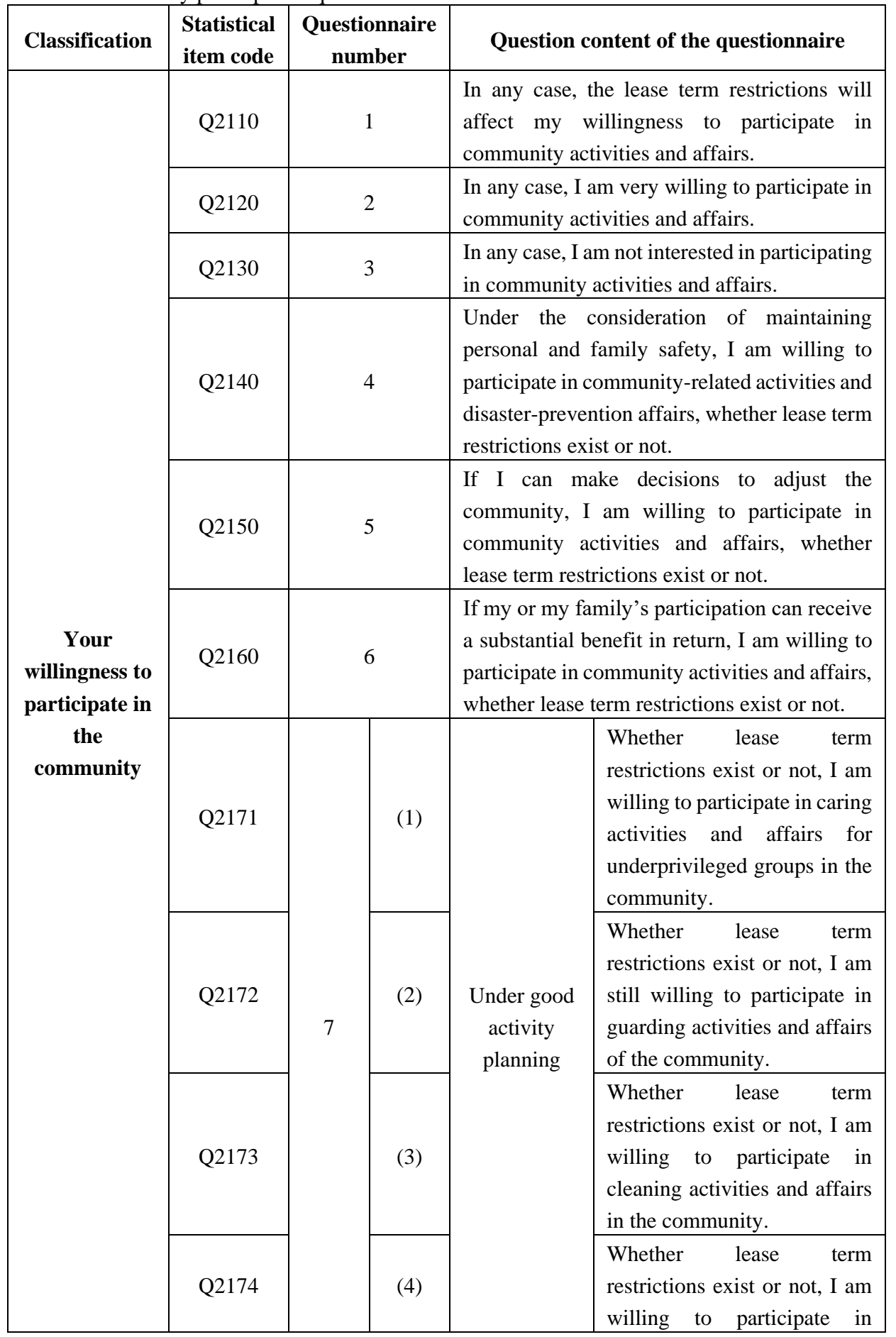




\begin{tabular}{|c|c|c|c|c|c|}
\hline & & & & & $\begin{array}{l}\text { leisure activities in the } \\
\text { community. }\end{array}$ \\
\hline & Q2175 & & (5) & & $\begin{array}{l}\text { Whether lease term } \\
\text { restrictions exist or not, I am } \\
\text { still willing to participate in } \\
\text { festival activities (Mid- } \\
\text { Autumn Festival, Mother's } \\
\text { Day, etc.) in the community. }\end{array}$ \\
\hline & Q2176 & & (6) & & $\begin{array}{l}\text { Whether lease term } \\
\text { restrictions exist or not, I am } \\
\text { still willing to participate in } \\
\text { travel activities in the } \\
\text { community. }\end{array}$ \\
\hline & Q2181 & & (1) & & $\begin{array}{l}\text { Whether lease term } \\
\text { restrictions exist or not, I am } \\
\text { willing to participate in caring } \\
\text { activities and affairs for } \\
\text { underprivileged groups in the } \\
\text { community. }\end{array}$ \\
\hline & Q2182 & & $(2)$ & & $\begin{array}{l}\text { Whether lease term } \\
\text { restrictions exist or not, I am } \\
\text { still willing to participate in } \\
\text { guarding activities and affairs } \\
\text { of the community. }\end{array}$ \\
\hline & Q2183 & 8 & (3) & Under good & $\begin{array}{l}\text { Whether lease term } \\
\text { restrictions exist or not, I am } \\
\text { willing to participate in } \\
\text { cleaning activities and affairs } \\
\text { in the community. }\end{array}$ \\
\hline & Q2184 & 8 & (4) & $\begin{array}{l}\text { community } \\
\text { relationship }\end{array}$ & $\begin{array}{l}\text { Whether lease term } \\
\text { restrictions exist or not, I am } \\
\text { willing to participate in } \\
\text { leisure activities in the } \\
\text { community. }\end{array}$ \\
\hline & Q2185 & & (5) & & $\begin{array}{l}\text { Whether lease term } \\
\text { restrictions exist or not, I am } \\
\text { still willing to participate in } \\
\text { the festival activities (Mid- } \\
\text { Autumn Festival, Mother's } \\
\text { Day, etc.) in the community. }\end{array}$ \\
\hline & Q2186 & & (6) & & $\begin{array}{l}\text { Whether lease term } \\
\text { restrictions exist or not, I am } \\
\text { still willing to participate in } \\
\text { travel activities in the } \\
\text { community. }\end{array}$ \\
\hline $\begin{array}{c}\text { Consideration } \\
\text { of community } \\
\text { participation }\end{array}$ & Q2210 & & & $\begin{array}{l}\text { I think that, ex } \\
\text { house, everyt } \\
\text { the communit }\end{array}$ & $\begin{array}{l}\text { ept the environment within my } \\
\text { ng else should be handled by } \\
\text { 's management organization. I }\end{array}$ \\
\hline
\end{tabular}




\begin{tabular}{|c|c|c|c|c|}
\hline & & & \multicolumn{2}{|c|}{$\begin{array}{l}\text { don't need to participate in related community } \\
\text { activities and affairs. }\end{array}$} \\
\hline Q2220 & \multicolumn{2}{|c|}{2} & \multicolumn{2}{|c|}{$\begin{array}{l}\text { The length of time that I stay in the community } \\
\text { is my main consideration to decide whether I } \\
\text { participate in community activities and affairs. }\end{array}$} \\
\hline Q2230 & & & \multicolumn{2}{|c|}{$\begin{array}{l}\text { Substantial assistance or benefits for me or my } \\
\text { family is my main consideration to decide } \\
\text { whether to participate in community activities } \\
\text { and affairs. }\end{array}$} \\
\hline Q2240 & & & \multicolumn{2}{|c|}{$\begin{array}{l}\text { Direct impact (home security, environmental } \\
\text { quality, etc.) on me or my family is the main } \\
\text { consideration for me to decide whether to } \\
\text { participate in community activities and affairs. }\end{array}$} \\
\hline Q2250 & & & \multicolumn{2}{|c|}{$\begin{array}{l}\text { Good community relations is the main } \\
\text { consideration for me to decide whether to } \\
\text { participate in community activities and affairs. }\end{array}$} \\
\hline Q2260 & & & \multicolumn{2}{|c|}{$\begin{array}{l}\text { Whether my participation can really make a } \\
\text { difference is the main consideration for me to } \\
\text { decide whether to participate in community } \\
\text { activities and affairs. }\end{array}$} \\
\hline Q2271 & \multirow{7}{*}{7} & (1) & \multirow{7}{*}{$\begin{array}{l}\text { I attend the } \\
\text { community } \\
\text { activities }\end{array}$} & $\begin{array}{l}\text { depending on whether my } \\
\text { time is free. }\end{array}$ \\
\hline Q2272 & & (2) & & $\begin{array}{l}\text { depending on the mood of the } \\
\text { day. }\end{array}$ \\
\hline Q2273 & & (3) & & $\begin{array}{l}\text { depending on whether the } \\
\text { activity is interesting. }\end{array}$ \\
\hline Q2274 & & (4) & & $\begin{array}{l}\text { depending on whether } \\
\text { neighbors I'm familiar with } \\
\text { will go. }\end{array}$ \\
\hline Q2275 & & (5) & & $\begin{array}{l}\text { depending on the degree that } \\
\text { the activity will affect me. }\end{array}$ \\
\hline Q2276 & & (6) & & $\begin{array}{l}\text { as long as I think it is a } \\
\text { meaningful activity, then I } \\
\text { will attend it regardless. }\end{array}$ \\
\hline Q2277 & & (7) & & I will not attend, regardless. \\
\hline
\end{tabular}

\subsubsection{Questionnaire reliability, validity and factor analysis}

For the 31 questions about community participation, 31 reliable questionnaires were distributed and collected. The alpha value, of the questionnaire in the reliability section, as shown in Table 3, is 0.838 , which means it is reliable. The constructive validity KMO value, as shown in Table 4, is 0.813 , which means the questionnaire is valid and suitable for factor analysis. As for item analysis, the item analysis of this study was tested using the Kolmogorov-Smimor one-sample test of nonparametric statistics. The significance level of the statistics was set to et to ected. The alpha value, of the questionnaire in the reliability section, as shown in Table 3, is ing deleted.

Table 3. Reliability Statistics

\begin{tabular}{l|l} 
Cronbach's Alpha & Number of items \\
\hline
\end{tabular}


Table 4. KMO \& Bartlett test

\begin{tabular}{l|l|r}
\hline Kaiser-Meyer-Olkin Measure of Sampling Adequacy & 0.813 \\
\hline Bartlett's test of Sphericity & Approximate. Chi-Square allocation & 1774.247 \\
\cline { 2 - 3 } & df & 465 \\
\cline { 2 - 3 } & Significance & 0.000 \\
\hline
\end{tabular}

\section{RESULUTS AND DISCUSSIONS}

We analyzed basic data of the tested people who are eligible and willing to rent. The mean value of responses to each item is our reference to test peoples' intention and the basis of an individual's comparative analysis. The mean value of the responses to "how the lease term restrictions affect the participation willingness" is the standard for us to further compare and analyses tested peoples' intention to items "Residents' willingness to participate in the community activities" and "Residents' consideration of community participation". This analysis helps us to understand tested peoples' opinions and intentions toward each item, and we can use this as the foundation for further research and analysis.

\subsection{Basic data analysis}

According to statistical analysis, the number of males accounts for $46 \%$ of the total tested people and the number of females accounts for $54 \%$, which shows that the number of females is larger. As for the age, the number of people aged 20-34 accounts for $50 \%$ of the total tested samples, the second is people aged 35-44, accounting for $33 \%$. As for the current location, people from Taipei City account for $49 \%$ of the total tested samples and people from New Taipei City account for $51 \%$. In terms of occupation, the service industry (freelancer) has the largest number of people, accounting for $42 \%$ of the total, and the second largest group comes from the manufacturing industry, accounting for $25 \%$. As for the academic background, graduate or above degree accounts for $43 \%$ of the total tested samples, the second is university degree, accounting for $42 \%$. For marital condition, single people account for $67 \%$ of the total samples and married people accounts for $33 \%$. The amount of people having children under the age of 18 in the family accounts for $19 \%$ of the total tested samples and the number of people who do not accounts for $81 \%$. People who have served a position in a community self-governing body account for $10 \%$ of the total tested samples and people who have not account for $90 \%$. According to the above description: the sample of this questionnaire includes more females; the age concentrates more in the range of 20-34 and 35-44; people evenly come from Taipei City and New Taipei City; most people work in the service industry (freelancer); and most peoples' academic background evenly distributes across a university degree, or graduate and above degree. Single people, people without children under the age of 18 at home and people who do not serve a position in a community self-government body remain the larger groups. 
Table 5. Basic data of the questionnaire

\begin{tabular}{|c|c|c|c|}
\hline \multicolumn{3}{|c|}{$\begin{array}{l}\text { Sample: } 72 \text { people in total who are eligible and willing to } \\
\text { rent. }\end{array}$} & Explanation \\
\hline \multirow{2}{*}{ Gender rate } & Males & Females & \multirow{2}{*}{ - More female samples. } \\
\hline & $46 \%$ & $54 \%$ & \\
\hline \multirow{2}{*}{$\begin{array}{l}\text { Proportion of } \\
\text { the sample's age }\end{array}$} & 20-34 years old & $35-44$ years old & \multirow{2}{*}{$\begin{array}{l}\text { The age concentrates more in the } \\
\text { range of } 20-34 \text { and } 35-44 \text {. }\end{array}$} \\
\hline & $50 \%$ & $33 \%$ & \\
\hline \multirow{2}{*}{$\begin{array}{l}\text { Proportion of } \\
\text { the sample's } \\
\text { living area }\end{array}$} & Taipei City & New Taipei City & \multirow{2}{*}{$\begin{array}{l}\text { Samples evenly come from Taipei } \\
\text { - City and New Taipei City. No } \\
\text { significant differences. }\end{array}$} \\
\hline & $49 \%$ & $51 \%$ & \\
\hline \multirow{2}{*}{$\begin{array}{l}\text { Proportion of } \\
\text { sample's } \\
\text { occupation }\end{array}$} & $\begin{array}{l}\text { The service } \\
\text { industry } \\
\text { (freelancer) }\end{array}$ & $\begin{array}{l}\text { The manufacturing } \\
\text { industry }\end{array}$ & \multirow{2}{*}{$\begin{array}{l}\text { Most samples work in the service } \\
\text { industry (freelance). }\end{array}$} \\
\hline & $42 \%$ & $25 \%$ & \\
\hline \multirow{2}{*}{$\begin{array}{l}\text { Proportion of } \\
\text { the sample's } \\
\text { academic } \\
\text { background }\end{array}$} & $\begin{array}{l}\text { Graduate and } \\
\text { above degree }\end{array}$ & University degree & \multirow{2}{*}{$\begin{array}{l}\text { Most samples' academic } \\
\text { background evenly distributes } \\
\text { across the category of university } \\
\text { \% degree, or graduate and above } \\
\text { degree. }\end{array}$} \\
\hline & $43 \%$ & $42 \%$ & \\
\hline \multirow{2}{*}{$\begin{array}{l}\text { Proportion of } \\
\text { the sample's } \\
\text { marital } \\
\text { condition }\end{array}$} & Single & Married & \multirow[b]{2}{*}{ More single samples. } \\
\hline & $67 \%$ & $33 \%$ & \\
\hline \multirow{2}{*}{$\begin{array}{l}\text { Proportion of } \\
\text { whether sample } \\
\text { has children } \\
\text { under the age of } \\
18\end{array}$} & Yes & No & \multirow[b]{2}{*}{$\begin{array}{l}\text { More samples have no children } \\
\text { under the age of } 18 \text { in the family. }\end{array}$} \\
\hline & $19 \%$ & $81 \%$ & \\
\hline \multirow{2}{*}{$\begin{array}{l}\text { Proportion of } \\
\text { whether sample } \\
\text { has served in a } \\
\text { position in the } \\
\text { community self- } \\
\text { governing body }\end{array}$} & Yes & No & \multirow[b]{2}{*}{$\begin{array}{l}\text { More samples have served in a } \\
\text { position in the community self- } \\
\text { governing body. }\end{array}$} \\
\hline & $10 \%$ & $90 \%$ & \\
\hline
\end{tabular}

\subsection{Residents' willingness to participate in the community activities}

\subsubsection{Overall opinion}

There are 18 questions about residents' willingness to participate, and the statistical results are shown in Table 6.

Table 6. Single Sample Kolmogorov-Smirnov Testing Statistics Chart of the willingness of community participation

\begin{tabular}{|c|c|c|c|c|c|c|c|c|c|c|c|c|c|c|c|c|c|c|c|}
\hline & & Q2110 & Q2120 & Q2130 & Q2140 & Q2150 & Q2160 & Q2171 & Q2172 & Q2173 & Q2174 & Q2175 & Q2176 & Q2181 & Q2182 & Q2183 & Q2184 & Q2185 & Q2186 \\
\hline \multicolumn{2}{|c|}{ Number } & 72 & 72 & 72 & 72 & 72 & 72 & 72 & 72 & 72 & 72 & 72 & 72 & 72 & 72 & 72 & 72 & 72 & 72 \\
\hline \multirow{2}{*}{$\begin{array}{c}\text { normal } \\
\text { parameter } \\
\text { a,b }\end{array}$} & mean & 3.57 & 3.15 & 2.64 & 3.60 & 3.57 & 3.74 & 3.50 & 3.42 & 3.49 & 3.64 & 3.49 & 3.47 & 3.51 & 3.53 & 3.60 & 3.65 & 3.64 & 3.57 \\
\hline & $\begin{array}{l}\text { standard } \\
\text { deviation }\end{array}$ & 1.032 & .816 & 939 & .899 & .784 & .769 & .787 & .801 & .822 & .844 & .872 & 903 & .856 & 919 & .816 & .906 & .924 & .885 \\
\hline
\end{tabular}




\begin{tabular}{|c|c|c|c|c|c|c|c|c|c|c|c|c|c|c|c|c|c|c|c|}
\hline \multirow{3}{*}{$\begin{array}{l}\text { maximum } \\
\text { difference }\end{array}$} & absolute & .287 & .296 & .205 & .219 & .238 & .259 & .279 & .254 & .262 & .277 & .222 & .248 & .226 & .210 & .259 & .260 & .235 & .242 \\
\hline & positive & .199 & .296 & .196 & .219 & .238 & .213 & .196 & .254 & .197 & .209 & .211 & .182 & .226 & .203 & .200 & .198 & .181 & .188 \\
\hline & minus & -.287 & -.273 & -.205 & -.201 & -.236 & -.29 & -.279 & -.211 & -.262 & -.277 & -.222 & -.248 & -.215 & -.210 & -.259 & -.260 & -.235 & -.242 \\
\hline \multicolumn{2}{|c|}{$\begin{array}{l}\text { Kolmogorov- } \\
\text { Smirnov Z Test }\end{array}$} & 2.433 & 2.515 & 1.742 & 1.859 & 2.023 & 2.200 & 2.367 & 2.157 & 2.222 & 2.348 & 1.885 & 2.106 & 1.917 & 1.784 & 2.194 & 2.209 & 1.997 & 2.055 \\
\hline \multicolumn{2}{|c|}{$\begin{array}{l}\text { Asymptotic } \\
\text { significance } \\
\text { (two-sided) }\end{array}$} & .000 & .000 & .005 & .002 & .001 & .000 & .000 & .000 & .000 & .000 & .002 & .000 & .001 & .003 & .000 & .000 & .001 & .000 \\
\hline
\end{tabular}

The significant level of the statistics is set to $\alpha=0.05$, and the significance $p$ of all items is less than 0.05 .

The mean of item Q2110 (how lease term restrictions affect the participation willingness) is 3.57 , which shows that lease term restrictions do affect the willingness of residents. If the mean value of Q2110 is the standard, the rank of the items above the standard from high to low in order are Q2160 (receive substantial benefit in return; mean: 3.74), Q2184 (leisure activities under good community relations; mean: 3.65), Q2185 (festival activities; mean: 3.64), Q2174 (leisure activities under good activity planning; mean: 3.64), Q2183 (house cleaning under good community relations; mean: 3.60), Q2140 (considerations of safety maintenance; mean: 3.60) and Q2150 (making decisions to change the community; mean: 3.57). Out of all the items, only Q2130 (not interested in participating; mean: 2.64) results toward disagreement while the other means are all greater than 3.00, resulting toward agreement. The comparison of each mean is detailed in Figure 2.

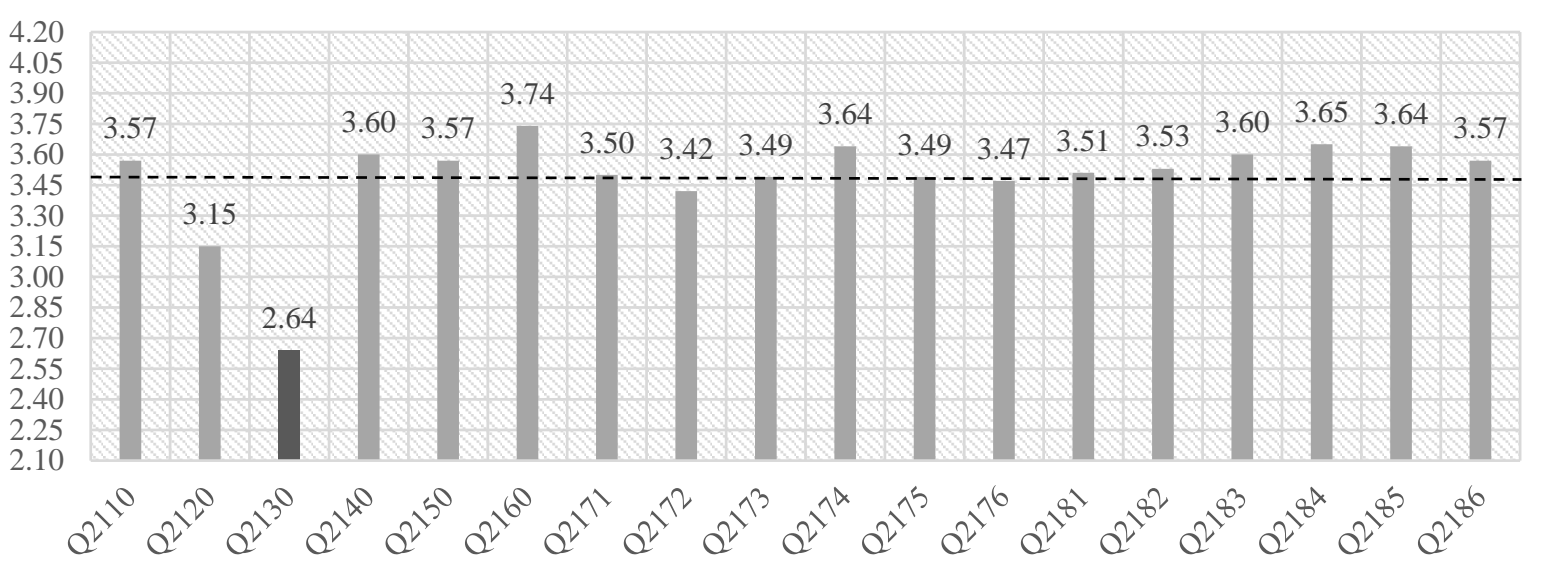

Figure 2. Comparison of the means of each questionnaire item

\subsubsection{Discrepancy between gender's caring degree of each item}

According to the statistical result, for Q2110 (how lease term restrictions affect the participation willingness), females compared to males care more, but for all other items, such as Q120 (willing to participate in community activity), Q2172 (willing to participate guarding activities in community), Q2174 (willing to participate in leisure activities) and Q2176 (willing to participate in travelling activities), males compared to females care more, and the discrepancy is significant. Except for the items mentioned above, significant discrepancy on caring degree does not exist between gender. Statistical results are displayed in Table 7 (only items with significant discrepancy are listed). 
Table 7. Hypothesis test summary by gender

\begin{tabular}{|c|c|c|c|c|c|c|c|}
\hline $\begin{array}{l}\text { Statistical item } \\
\text { code }\end{array}$ & Gender & $\mathrm{N}$ & Mean & $\begin{array}{c}\text { Std. } \\
\text { Deviation }\end{array}$ & $\begin{array}{l}\text { Std. Error } \\
\text { Mean }\end{array}$ & Sig. & \\
\hline \multirow[t]{2}{*}{ Q2110 } & males & 33 & 3.27 & 1.126 & 0.196 & \multirow{2}{*}{0.024} & \multirow{2}{*}{$*$} \\
\hline & females & 39 & 3.82 & 0.885 & 0.142 & & \\
\hline \multirow[t]{2}{*}{ Q2120 } & males & 33 & 3.33 & 0.816 & 0.142 & \multirow{2}{*}{0.042} & \multirow{2}{*}{$*$} \\
\hline & females & 39 & 3.00 & 0.795 & 0.127 & & \\
\hline \multirow[t]{2}{*}{ Q2172 } & males & 33 & 3.67 & 0.777 & 0.135 & \multirow{2}{*}{0.024} & \multirow{2}{*}{$*$} \\
\hline & females & 39 & 3.21 & 0.767 & 0.123 & & \\
\hline \multirow[t]{2}{*}{ Q2174 } & males & 33 & 3.88 & 0.781 & 0.136 & \multirow{2}{*}{0.039} & \multirow{2}{*}{$*$} \\
\hline & females & 39 & 3.44 & 0.852 & 0.136 & & \\
\hline \multirow[t]{2}{*}{ Q2176 } & males & 33 & 3.73 & 0.801 & 0.139 & \multirow{2}{*}{0.037} & \multirow{2}{*}{$*$} \\
\hline & females & 39 & 3.26 & 0.938 & 0.150 & & \\
\hline
\end{tabular}

Asymptotic significances are displayed. The significance level is 0.05 .

\subsubsection{Discrepancy between different ages' caring degree for each item}

According to the statistical result, there is no significant discrepancy between different ages' caring degree on each item.

\subsection{Residents' consideration of community participation}

\subsubsection{Overall findings}

There are 13 items inquiring residents' consideration of community participation and the statistical results are shown in Table 8.

Table 8. One-Sample Kolmogorov-Smirnov Test Statistics table of consideration of community participation

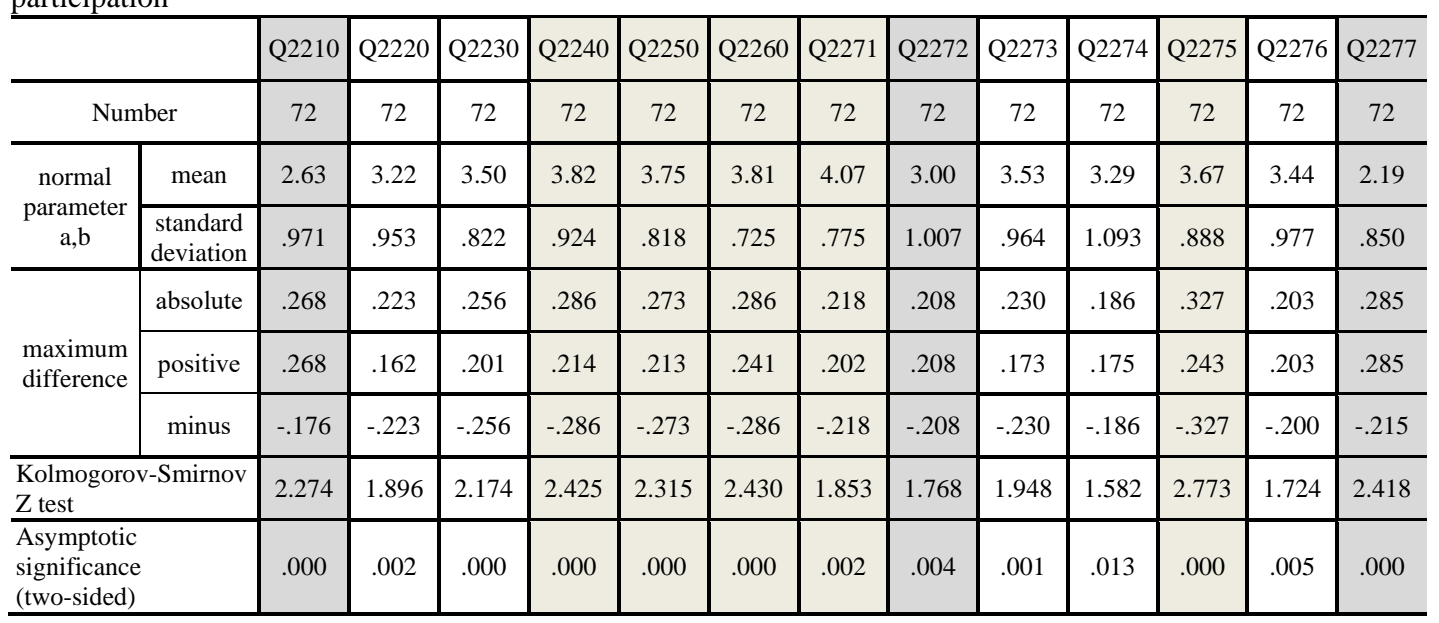

If we also adopt the mean value of participation willingness 3.57 as the standard, the high to low rank of participation considered items which are above the standard is Q2271 (participation depends on whether they have free time; mean: 4.07), Q2240 (direct impact on individuals or their family is the main consideration; mean: 3.82), Q2260 (whether their participation can really adjust 
the community is the main consideration; mean: 3.81), Q2250 (good community relations is the main consideration; mean: 3.75) and Q2275 (the extent to which the content of the activity will affect them; mean: 3.67). In all items except Q2210 (manage one's housing without any need to participate in community activities; mean: 2.63), Q2277 (will not attend it, regardless; mean: 2.19) and Q2272 (depends on the mood of the day; mean 3.00) result less toward agreement or more toward disagreement; other means are greater than 3.00, which leans more toward agreement. Comparison of each item's mean value is detailed in Figure 3.

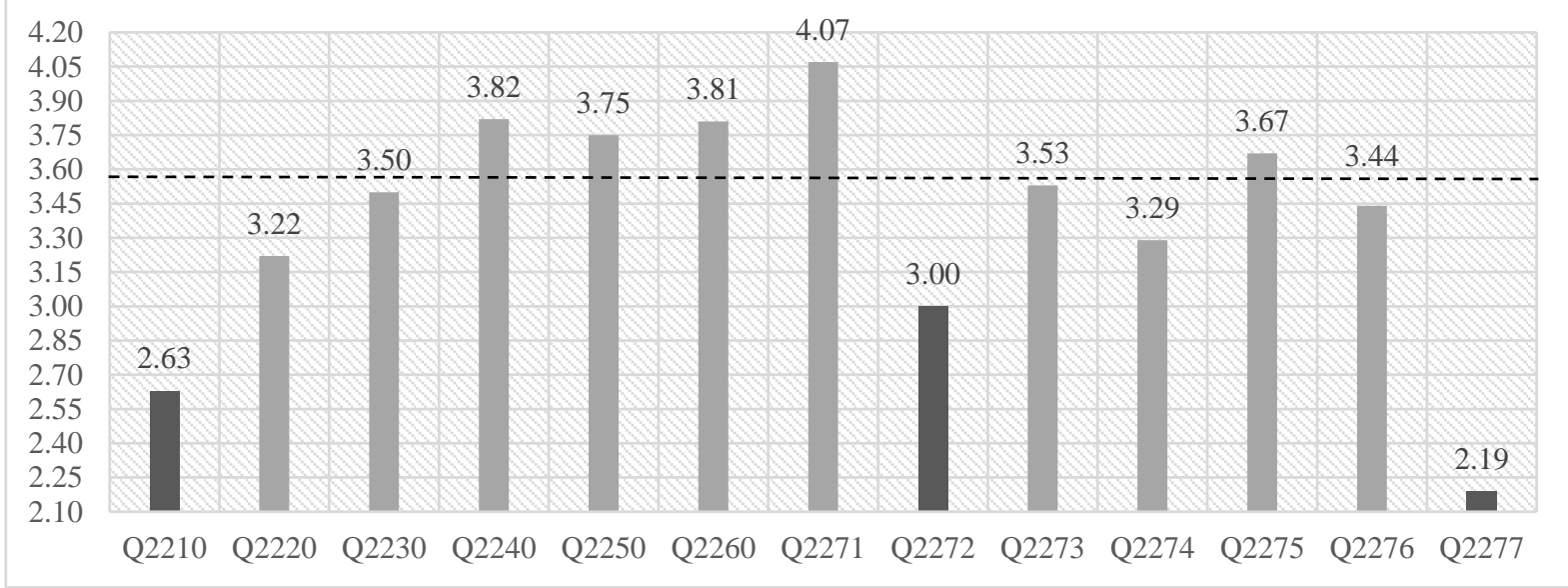

Figure 3. Comparison of community participation consideration's mean

\subsubsection{Discrepancy between gender's caring degree of each item}

According to the statistical result, Q2220 (the length of time that I stay in the community) shows that females, compared to males, care more, but for all the other items mentioned above, a significant discrepancy on caring degree does not exist between gender. Statistical results are displayed in Table 9 (only items with significant discrepancy are listed).

Table 9. Hypothesis test summary for gender

\begin{tabular}{c|c|r|r|r|r|r|r}
\hline $\begin{array}{c}\text { Statistical } \\
\text { item code }\end{array}$ & Gender & $\mathbf{N}$ & Mean & $\begin{array}{c}\text { Std. } \\
\text { Deviation }\end{array}$ & $\begin{array}{c}\text { Std. } \\
\text { Error Mean }\end{array}$ & Sig. & \\
\hline \multirow{2}{*}{ Q2220 } & males & 33 & 2.97 & 1.045 & 0.182 & \\
\cline { 2 - 5 } & females & 39 & 3.44 & 0.821 & 0.131 & 0.042 & $*$ \\
\hline
\end{tabular}

Asymptotic significances are displayed. The significance level is 0.05 .

\subsubsection{Discrepancy between different ages' caring degree for each item}

According to the statistical result, there is no significant discrepancy between different ages' caring degree on each item.

\subsection{Discussions}

According to the results of the research, although the tested sample's willingness to participate in the community is affected by the lease term restrictions, they overall will have more motivation to participate in the community as long as they have enough time or the relationship of the 
neighborhood remains well. In addition, whether their decision can make an actual change or a direct impact on them and their family are also driving factors. In terms of participation willingness, relaxing leisure activities, festival activities, activities that give substantial benefit, and activities that maintain the safety and hygiene of the community can increase peoples' willingness to participate. On the other hand, though activities such as caring for unprivileged groups or guarding for neighbors do increase peoples' willingness to participate, the degree is relatively low. Peoples' caring degree for these activities is also lower than the effect of the lease term restrictions. In terms of the relationship between the tested samples' gender and their caring degree on different items, female community participation is more influenced by lease term restrictions and the length of time they have stayed. Male willingness to participate in guarding, community leisure activities and travel activities is higher than for females. The discrepancy between different ages' caring degrees is not significant.

The results presented in this study can be discussed from the perspective of "Egoism" merged with "Expectation value theory". The actor must always be the beneficiary of self-action, and the person must act for their own rational selfinterest. However, the reason for one's action is derived from an individual's human nature and the moral values of one's life (Ayn, 1964). That is, individuals should be the ultimate beneficiary of their self-ethical action(Lin, 2004). Egoism is not pure selfishness. The difference between egoism and altruism lies in whether the motivation of the ultimate action can help develop one's selfhappiness (Schulz, 2016), and most of the motivational orientations can be clarified by the expectation value theory and elaborated by the following equation: Motivation $=$ Expectation $*$ Value ( $\mathrm{Liu}, 2003)$. In other words, altruism is possible in egoism, but the consideration of altruistic action is to sacrifice short-term benefits for long-term benefits, and the ultimate goal of it is to maximize selfinterest. Therefore, to trigger motivation toward long-term community participation, egoism thoughts can be considered for the design and promotion of community activities.

\section{CONCLUSIONS AND SUGGESTIONS}

\subsection{Conclusions}

During the early period in which the supply and demand of social housing still have not been balanced, lease term restrictions of social housing have become an expedient policy that can take care of more residents with housing requirements, but these restrictions may also affect residents' willingness and motivation to participate in community affairs or to jointly maintain the quality of the living environment. The result of this study shows that the current leasing term restrictions of social housing may affect the residents' willingness of community participation to some extent, but residents still have a rational attitude toward community participation. Responses to negative questions such as not participating or depending on the mood of the day are more towards disagreement. As for easier leisure activities, festival activities, activities which give substantial benefits in return, and activities maintaining environmental hygiene and safety, their impact on participation willingness is greater than the impact of the lease term restrictions. Personal time allowance and direct impacts on the individual or 
their family members are an individual's focal point of their consideration. Being able to make effective changes has a greater impact on people's willingness and consideration than lease term restrictions, and the correlation between good community relations and willingness and consideration to participate is positive.

The study shows that easier leisure activities, festival activities, activities where individuals can get substantial benefits in return, activities that maintain environmental hygiene and safety are easy to achieve engagement, and their value is more immediate or short-term oriented, which makes them suitable to be adopted as a short-term strategy to generate people's motivation to participate. Activities that make a direct impact on individuals and their family members, and that actually changes the community, has higher expectations. Once they are held successfully, the value that an individual can obtain is relatively higher, which makes them suitable for a medium-term strategy. Activities such as underprivileged groups caring and mutual helping and protecting are less able to

show the actual expected value for the individual. Though people reach positive consensus toward these activities, the average is low. For these activities, they can be adopted as a long-term strategy by utilizing egoism's ultimate motivation purpose on maximizing one's personal interest and suggesting policy adjustment.

\subsection{Suggestions}

After conducting analyses and concluding the results based on the survey of social housing residents' willingness and considerations of community participation, the short-term, medium-term and long-term strategies that trigger community participation and motivation under the influence of lease term restrictions are suggested:

(1) Short-term strategy suggestion:

Conduct leisure activities, festival activities and activities that maintain the environmental hygiene and safety to provide substantive feedback. This activities' purpose aims to create a friendly community that residents can participate in, increase opportunities for neighbors to interact and build good neighborhood relations. Furthermore, construct a preliminary community information platform and a network of software and hardware-based information to establish a complete management system and facilitate subsequent maintenance management.

(2) Medium-term strategy suggestion:

Apply existing popular online communities and try to let people participate and express their thoughts about certain issues online so that people's time problem can be solved. This strategy aims to increase the popularity and success rate of activities that have a direct impact on residents and that can really make changes.

(3) Long-term strategy suggestion:

Propose detailed adjustment and adjustment plans for social housing-related management law, and provide an extension of the lease term for residents who are enthusiastic about community public affairs and those who actually participate in altruistic activities such as underprivileged caring based on some conditions so that people participate more in these kinds of activities. 


\section{REFERENCES}

Ayn, R. (1964). The Virtue of Selfishness. New York: New American Library.

Chang, K.-C., \& Sung, B.-M. (2010). "The Relationships between Community Sense and Residents' Participation: Partnership as the Moderator". Journal of Tourism and Travel Research, 5(2), 5176.

Flint, J. (2004). "Reconfiguring Agency and Responsibility in the Governance of Social Housing in Scotland". Urban Studies, 41(1), 151-172. doi: https://doi.org/10.1080/0042098032000155722.

Huang, L., Dan, Y.-Z., Xu, J.-F., \& Tong, M. (2018). "From Concept to Action: Practice and Thinking in Urban Community Development and Community Planning in Chongqing". International Review for Spatial Planning and Sustainable Development, 6(2), 1-11. doi: https://doi.org/10.14246/irspsda.6.2 1.

Li, C.-H. (2010). "Sense of Community among Inhabitants in Taiwan: An Analysis of the Systemic Model". Journal of City and Planning, 37(2), 209-231.

Liao, C.-S. (2012). "Community Empowerment in Social Housing: An Action Research of Bodhi Chang Ching Village". Journal of Environment \& Art, 12, 66-89.

Lin, H. W. (2004). Ethics. Taipei: Wu-Nan Book Inc.

Liu, W.-T. (2003). "A Strategy to Promote Learning Motivation in an Use of Expectancy-Value Theory". Journal of Chung Chou, (18), 254-272.

Maya-Jariego, I., \& Holgado, D. (2015). "Living in the Metropolitan Area. Correlation of Interurban Mobility with the Structural Cohesion of Personal Networks and the Originative Sense of Community". Psychosocial Intervention, 24(3), 185-190. doi: https://doi.org/10.1016/j.psi.2015.09.001.

Petković-Grozdanović, N., Stoiljković, B., Jovanović, G., Mitković, P., \& Keković, A. (2017). "The Spatial Comfort of Social Housing Units in the Post-Socialist Period in Serbia in Relation to the Applicable Architectural Norms". Cities, 62, 88-95. doi: https://doi.org/10.1016/i.cities.2016.12.014.

Schulz, A. W. (2016). "Altruism, Egoism, or Neither: A Cognitive-Efficiency-Based Evolutionary Biological Perspective on Helping Behavior". Studies in History and Philosophy of Science Part C: Studies in History and Philosophy of Biological and Biomedical Sciences, 56, 15-23. doi: https://doi.org/10.1016/j.shpsc.2015.10.006.

Simmel, G. (2012). "The Metropolis and Mental Life". In Lin, J. \& Mele, C. (Eds.), The Urban Sociology Reader (pp. 37-45). London: Routledge.

Tsuang, H.-C., \& Peng, K.-H. (2018). "The Livability of Social Housing Communities in Taiwan: A Case Study of Taipei City". International Review for Spatial Planning and Sustainable Development, 6(3), 4-21. doi: https://doi.org/10.14246/irspsd.6.3_4.

Wang, Y. (2014). "The Framework of Social Sustainability for Chinese Communities: Revelation from Western Experiences". International Review for Spatial Planning and Sustainable Development, 2(3), 4-17. doi: https://doi.org/10.14246/irspsd.2.3 4.

Wei, Z., Wang, B., Chen, T., \& Lin, Y. (2016). "Community Development in Urban Guangzhou since 1980: A Social Sustainability Perspective". International Review for Spatial Planning and Sustainable Development, 4(4), 58-68. doi: https://doi.org/10.14246/irspsd.4.4 58. 